\title{
Trends in the use of hematopoietic stem cell transplantation for adults with acute lymphoblastic leukemia in Europe: a report from the Acute Leukemia Working Party of the European Society for Blood and Marrow Transplantation (EBMT)
}

\author{
Sebastian Giebel ${ }^{1}$ (D) Ariane Boumendil ${ }^{2,3}$ - Myriam Labopin $^{2,3}$ - Anouchka Seesaghur ${ }^{4}$. Frederic Baron ${ }^{5}$. \\ Fabio Ciceri ${ }^{6} \cdot$ Jordi Esteve $^{7} \cdot$ Norbert-Claude Gorin $^{2,3} \cdot$ Bipin Savani $^{8} \cdot$ Christoph Schmid $^{9} \cdot$ Sally Wetten $^{4}$. \\ Mohamad Mohty ${ }^{2}$. Arnon Nagler ${ }^{3,10}$
}

Received: 18 January 2019 / Accepted: 29 July 2019 / Published online: 7 August 2019

(C) The Author(s) 2019

\begin{abstract}
Hematopoietic stem cell transplantation (HSCT) is considered an effective way to prevent relapse in adults with acute lymphoblastic leukemia (ALL). This study aimed to assess general trends in the use of various types of HSCTs performed between 2001 and 2015 in Europe, based on data reported to the European Society for Blood and Marrow Transplantation registry. We also evaluated HSCT rates with respect to ALL incidence in selected countries. Altogether, 15,346 first allogeneic $(n=13,460)$ or autologous $(n=1886)$ HSCTs were performed in the study period. Comparing 2013-2015 and 2001-2003, the number of allogeneic HSCTs performed in first complete remission increased by $136 \%$, most prominently for transplantations from unrelated $(272 \%)$ and mismatched related donors (339\%). The number of HSCTs from matched sibling donors increased by $42 \%$, while the total number of autologous HSCTs decreased by 70\%. Increased use of allogeneic HSCT was stronger for Philadelphia chromosome $(\mathrm{Ph})$-positive $(166 \%)$ than for Ph-negative ALL $(38 \%)$ and for patients aged > 55 years $(599 \%)$ than for younger adults (59\%). The proportion of allogeneic HSCT with reduced-intensity conditioning (RIC) increased from 6 to $27 \%$. The agestandardized rates of allogeneic HSCT per ALL incidence varied strongly among countries. Our analysis showed a continued trend toward increased allogeneic HSCT use for adults with ALL, which may be attributed to increasing availability of unrelated donors, wider use of RIC regimens, and improving efficacy of pretransplant therapy, including tyrosine kinase inhibitors for Phpositive ALL. Allogeneic HSCT remains a major tool in the fight against ALL in adults.
\end{abstract}

Initial results of the study were reported as oral presentation during the 21 st Congress of the European Hematology Association in Copenhagen (2016).

Sebastian Giebel sgiebel@io.gliwice.pl

1 Department of Bone Marrow Transplantation and Onco-Hematology, Maria Sklodowska-Curie Institute - Oncology Center, Gliwice Branch, Str. Wybrzeze Armii Krajowej 15, 44-101 Gliwice, Poland

2 Clinical Hematology and Cellular Therapy Department, Hospital Saint-Antoine, 84 Rue du Faubourg Saint-Antoine, 75012 Paris, France

3 EBMT Acute Leukemia Working Party Office, Hospital Saint-Antoine, 84 Rue du Faubourg Saint-Antoine, 75012 Paris, France

4 Amgen Limited, 1 Uxbridge Business Park, Sanderson Road, Uxbridge, London UB8 1DH, UK
5 Department of Hematology, CHU Sart-Tilman, University of Liège, Avenue de L'Hòpital 1, 4000 Liège, Belgium

6 Hematology and BMT Unit, IRCCS San Raffaele Scientific Institute, Via Olgettina Milano, 60, Segrate, 20132 Milan, Italy

7 Hematology Department, IDIBAPS, Hospital Clinic, Carrer del Rosselló, 149, 08036 Barcelona, Spain

8 Department of Hematology \& Transplantation, Vanderbilt University, 2201 West End Ave, Nashville, TN 37235, USA

9 Department of Hematology and Oncology, Klinikum Augsburg, Ludwig-Maximilians-Universitaet Munich, Stenglinstraße 2, 86156 Augsburg, Germany

10 Division of Hematology and Bone Marrow Transplantation, Chaim Sheba Medical Center, Tel-HaShomer, Derech Sheba 2, Ramat Gan, Israel 
Keywords Acute lymphoblastic leukemia $\cdot$ Allogeneic hematopoietic stem cell transplantation $\cdot$ Autologous hematopoietic stem cell transplantation $\cdot$ Incidence

\section{Introduction}

Acute lymphoblastic leukemia (ALL) is one of the most aggressive malignancies. It is usually sensitive to multi-agent chemotherapy, which allows the initial achievement of complete remission (CR) in the majority of cases [1]. Nonetheless, approximately half of the patients achieving initial CR will relapse, which is associated with a very poor prognosis [2]. Allogeneic hematopoietic stem cell transplantation (HSCT) is considered an effective way to prevent relapse. It offers a chance to use myeloablative doses of chemotherapy and/or radiotherapy and may be associated with the beneficial graftversus-leukemia reaction mediated by $\mathrm{T}$ cells of donor origin.

The efficacy of allogeneic HSCT was confirmed in prospective trials conducted in the 1990s, comparing long-term outcome in subgroups defined based on the availability of human leukocyte antigen (HLA)-matched sibling donor (MSD) $[3,4]$. In the twenty-first century, with a growing number of registered volunteers, a chance of finding an HLA-compatible unrelated donor (URD) increased markedly [5]. Finally, novel immunosuppressive protocols have been elaborated, allowing for transplantations from partially mismatched related donors (MMRDs), namely haploidentical donors [6].

Unfortunately, HSCT is associated with a significant risk of life-threatening complications, among which infections and graft-versus-host disease are the most frequent causes of death. Despite improvement observed over time, the estimated risk of nonrelapse mortality remains $15 \%$ for HSCTs from MSDs and $22 \%$ for HSCTs from URDs [7]. Therefore, many national study groups attempt to reduce the indications for HSCT in favor of more intensive conventional dose chemotherapy. A strict evaluation of response based on minimal residual disease (MRD) assessment allows for a more precise identification of patients at lower risk of relapse. Furthermore, new and more active therapeutic options have been developed and introduced into clinical practice in advanced disease, including immunotoxins, bispecific $\mathrm{T}$ cell enhancers, and chimeric antigen receptor T cells [8-11]. For ALL with the presence of $t(9 ; 22)$, called Philadelphia chromosome $(\mathrm{Ph})$, new generations of tyrosine kinase inhibitors (TKIs) with strong anti- $A B L$ activity became available, offering highly effective ways of targeted therapy [12].

Taken together, the role of HSCT in the treatment of adults with ALL is a subject of debate. The goal of the current study was to analyze trends in the use of HSCT for adults with ALL in Europe. Data were analyzed as absolute number of procedures performed in subsequent time periods and relative to ALL incidence in selected countries. Finally, we looked at associations between the use of HSCT and socioeconomic factors.

\section{Methods}

This is a retrospective registry-based analysis on behalf of the Acute Leukemia Working Party (ALWP) of the European Society for Blood and Marrow Transplantation (EBMT).

The EBMT is a voluntary working group of more than 500 transplant centers that are required to report all consecutive HSCTs and follow-ups once a year. The validation and quality control program includes the verification of computer printouts of the entered data, cross-checking with the national registries, and on-site visits of selected teams.

All allogeneic or autologous HSCTs performed in adult patients ( $\geq 18$ years old) with ALL, between 2001 and 2015, were included in the analysis. The number of procedures was reported in subsequent 3-year intervals (2001-2003, 2004 2006, 2007-2009, 2010-2012, and 2013-2015). The analysis included donor type, disease stage at transplantation, ALL subtypes, recipient age, type and intensity of conditioning regimen, and the source of hematopoietic stem cells.

For the selected 11 countries (Denmark, Finland, France, Germany, Italy, Netherlands, Norway, Poland, Russia, Spain, and Sweden), age-standardized rates (per 100 diagnosed ALL cases) of allogeneic HSCT performed in first CR were calculated from 2001 to 2015 for each country in which ALL incidence data were available. ALL diagnosis incidence data were based on publicly available data reported by country-specific populationbased cancer registries. This part of the analysis was restricted to patients aged 20 years or more. Allogeneic HSCT rates for the period 2013-2015 were further correlated with the Human Development Index (HDI) and gross domestic product (GDP) per capita. The values of HDI and GDP were obtained from the 2015 Human Development Report, published by the United Nations [13], referring to data from 2014 and 2013. Spearman test was used to evaluate the associations.

\section{Results}

\section{HSCT numbers according to donor type and disease stage}

Between 2001 and 2015, 15,346 first HSCT procedures were performed in 32 European countries, including 13,460 allogeneic and 1886 first autologous transplantations. Among allogeneic HSCTs, URDs were used in 6953 cases $(52 \%)$, followed by MSDs $(n=5740 ; 43 \%)$ and MMRDs $(n=767 ; 6 \%)$. A continued increase in the 
total number of allogeneic HSCTs was observed over time, mostly in patients in first CR (Table 1; Fig. 1). Comparing 2013-2015 and 2001-2003, the number of allogeneic HSCTs performed in first CR increased by $136 \%$, most prominently for transplantations from URDs (272\%) and MMRDs (339\%). In respective periods, the number of HSCTs from MSDs increased by $42 \%$. The number of allogeneic HSCTs for patients treated in second or subsequent $\mathrm{CR}$ was stable over time except for MMRD-HSCT, where an increase of $416 \%$ was observed. In contrast, the use of autologous HSCTs decreased over time, starting from 707 procedures performed in 20012003 to 211 procedures registered in 2013-2015.

Altogether, the proportion of allogeneic HSCTs analyzed by donor type changed in favor of URD (41\% versus $56 \%$ URD-HSCTs among all transplantations between 2001 and 2003 versus 2013 and 2015) and MMRD (5\% versus $10 \%)$.

\section{HSCT numbers by disease subtype}

Data regarding the presence of $\mathrm{Ph}$ status were available for approximately $55 \%$ of the recipients of allogeneic HSCT with B cell precursor ALL. In these patients, the absolute number of allogeneic transplantations increased over time for both $\mathrm{Ph}$-negative and $\mathrm{Ph}$-positive ALL; however, the increase was more pronounced for $\mathrm{Ph}$ positive versus $\mathrm{Ph}$-negative disease (166\% versus $38 \%$ from 2001-2003 to 2013-2015; Table 2). The proportion of transplants for Ph-positive ALL among allogeneic HSCT recipients with known karyotype increased from 31 to $40 \%$. In parallel, the number of autologous HSCTs decreased by $78 \%$ and $5 \%$ for $\mathrm{Ph}$-negative and $\mathrm{Ph}-$ positive ALL, respectively. Notably, between 2013 and 2015, patients with Ph-positive ALL constituted $47 \%$ of autologous HSCT recipients compared with $17 \%$ between 2001 and 2003.

Table 1 Trends in the use of hematopoietic stem cell transplantation according to donor type and disease status

\begin{tabular}{|c|c|c|c|c|c|c|}
\hline \multirow[t]{2}{*}{ Donor type } & \multirow[t]{2}{*}{ Disease stage at transplantation } & \multicolumn{5}{|l|}{ Years } \\
\hline & & $2001-2003$ & 2004-2006 & 2007-2009 & 2010-2012 & 2013-2015 \\
\hline \multirow[t]{5}{*}{ Allogeneic } & Total, $n$ & 1890 & 2221 & 2754 & 3115 & 3480 \\
\hline & CR1 & $1006(55)$ & $1347(62)$ & $1816(67)$ & $2108(69)$ & $2374(70)$ \\
\hline & $\mathrm{CR}>1$ & $398(22)$ & $468(22)$ & $556(20)$ & $588(19)$ & $660(19)$ \\
\hline & Relapsed/refractory & $413(23)$ & $357(16)$ & $343(13)$ & $357(12)$ & $353(10)$ \\
\hline & Unknown, $n$ & 73 & 49 & 39 & 62 & 93 \\
\hline \multirow[t]{5}{*}{ Matched sibling } & Total, $n$ & 1019 & 1104 & 1197 & 1231 & 1189 \\
\hline & CR1 & $606(62)$ & $737(68)$ & $823(70)$ & $867(72)$ & $860(74)$ \\
\hline & $\mathrm{CR}>1$ & $161(16)$ & $192(18)$ & $215(18)$ & $206(17)$ & $183(16)$ \\
\hline & Relapsed/refractory & $214(22)$ & $150(14)$ & $141(12)$ & $130(11)$ & $113(10)$ \\
\hline & Unknown, $n$ & 38 & 25 & 18 & 28 & 33 \\
\hline \multirow[t]{5}{*}{ Unrelated } & Total, $n$ & 782 & 1036 & 1456 & 1726 & 1953 \\
\hline & $\mathrm{CR} 1$ & $362(48)$ & $583(57)$ & 957 (67) & $1169(69)$ & $1347(71)$ \\
\hline & $\mathrm{CR}>1$ & $219(29)$ & $252(25)$ & $302(21)$ & $335(20)$ & $384(24)$ \\
\hline & Relapsed/refractory & $171(23)$ & 179 (18) & $176(12)$ & $191(11)$ & $176(10)$ \\
\hline & Unknown, $n$ & 30 & 22 & 21 & 31 & 46 \\
\hline \multirow[t]{5}{*}{ Mismatched related } & Total, $n$ & 89 & 81 & 101 & 158 & 338 \\
\hline & CR1 & $38(45)$ & $27(34)$ & $36(36)$ & $72(46)$ & $167(52)$ \\
\hline & $\mathrm{CR}>1$ & $18(21)$ & $24(30)$ & $39(39)$ & $47(30)$ & $93(29)$ \\
\hline & Relapsed/refractory & $28(33)$ & $28(35)$ & $26(26)$ & $36(23)$ & $64(20)$ \\
\hline & Unknown, $n$ & 5 & 2 & 0 & 3 & 14 \\
\hline \multirow[t]{5}{*}{ Autologous } & Total, $n$ & 707 & 496 & 272 & 158 & 211 \\
\hline & $\mathrm{CR} 1$ & $461(70)$ & 327 (69) & $164(61)$ & $135(72)$ & $156(80)$ \\
\hline & $\mathrm{CR}>1$ & $85(13)$ & $64(14)$ & $34(13)$ & $18(10)$ & $21(11)$ \\
\hline & Relapsed/refractory & $111(17)$ & $80(17)$ & $69(26)$ & $34(18)$ & $19(10)$ \\
\hline & Unknown, $n$ & 50 & 25 & 5 & 13 & 15 \\
\hline
\end{tabular}

Data are $n(\%)$ using non-missing data unless specified otherwise. Only first allogeneic or autologous transplantations were included in the analysis $C R$ complete remission; $C R 1$ first $\mathrm{CR}, C R>1 \mathrm{~s}$ or subsequent $\mathrm{CR}$ 
$\square$ Total $\square \mathrm{CR} 1 \square \mathrm{CR}>1 \quad \square$ Relapsed/refractory

a

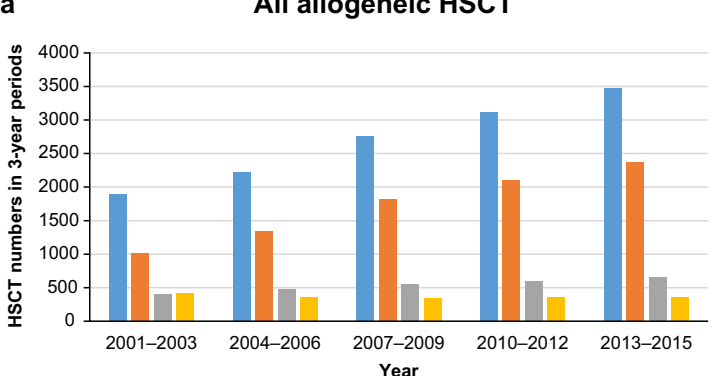

c

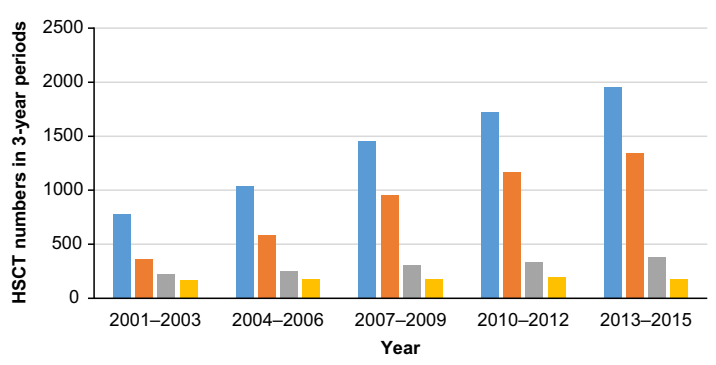

e

Autologous HSCT

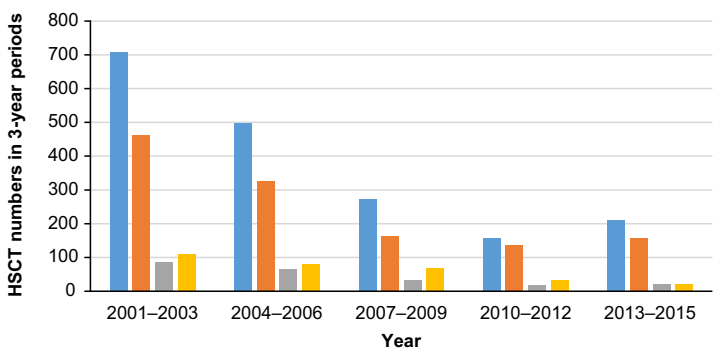

Fig. 1 Trends in the use of HSCT according to donor type and disease stage at transplantation. a All allogeneic HSCT. b Matched sibling donor HSCT. c Unrelated donor HSCT. d Mismatched related donor HSCT. e

Data on immune subtype were available for $92 \%$ of the patients treated with allogeneic HSCT and $93 \%$ of those treated with autologous HSCT. Similar trends were observed for both B cell precursor and T cell precursor ALL (Table 2). The number of allogeneic HSCTs was continuously increasing, while the number of autologous HSCTs was decreasing over time regardless of the immune subtype.

\section{HSCT and age}

Between 2001 and 2003, patients older than 55 years constituted $5 \%$ of all adults treated with allogeneic HSCT and $13 \%$ of those treated with autologous HSCT, while between 2013 and 2015, the proportions were $18 \%$ and $27 \%$, respectively (Table 3 ). The most prominent increase was observed for URD-HSCT (by $1415 \%$ ) and MMRD-HSCT (by 2300\%). The 55 years age limit is most frequently used by the European ALL study groups to

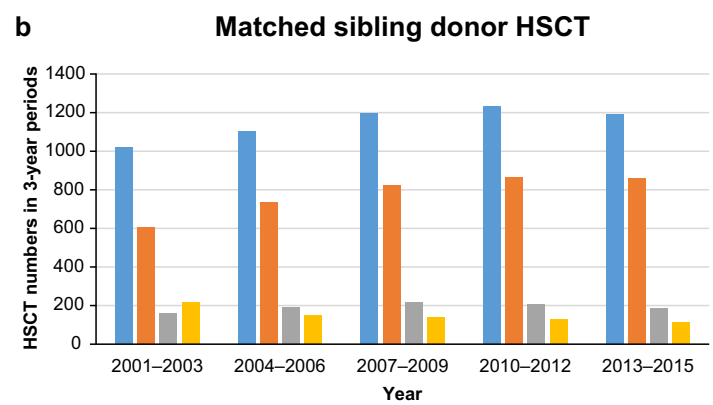

d Mismatched related donor HSCT

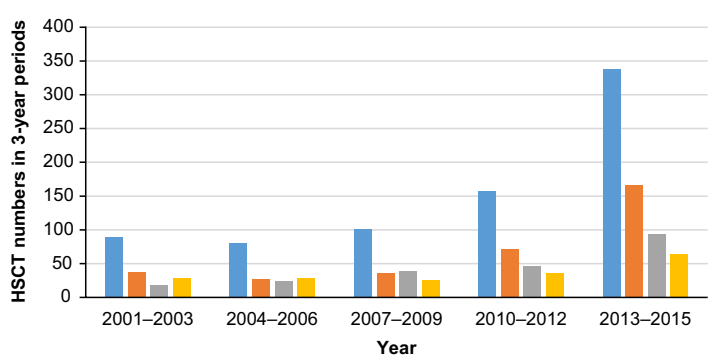

Autologous HSCT. $C R$ complete remission; $C R 1$ first $\mathrm{CR}, C R>1 \mathrm{~s}$ or subsequent $\mathrm{CR}$; HSCT hematopoietic stem cell transplantation

define patients' eligibility for intensive chemotherapy and myeloablative transplant procedures [14].

\section{Conditioning regimens and stem cell source}

Several aspects of the transplantation procedure, including the type of conditioning and source of hematopoietic stem cells, were analyzed for patients treated with allogeneic HSCT in first CR (Table 4). The proportion of transplantations with reduced-intensity conditioning (RIC) increased from $6 \%$ in 2001-2003 to 26\% in 2010-2012 [15]. Among myeloablative regimens, the use of total body irradiation (TBI) was predominant and stable over time, accounting for approximately $80 \%$ of all procedures. In contrast, chemotherapy-based regimens were more frequently used in the reduced-intensity setting, and their proportion increased from 53\% in 2001-2003 to $84 \%$ in $2013-2015$. 
Table 2 Trends in the use of hematopoietic stem cell transplantation according to disease subtype

\begin{tabular}{|c|c|c|c|c|c|c|c|}
\hline \multirow[t]{2}{*}{ Donor type } & \multirow[t]{2}{*}{ Disease subtype } & \multirow[t]{2}{*}{$\mathrm{Ph}$ status } & \multicolumn{5}{|l|}{ Years } \\
\hline & & & $\begin{array}{l}2001- \\
2003\end{array}$ & $\begin{array}{l}2004 \\
2006\end{array}$ & $\begin{array}{l}2007- \\
2009\end{array}$ & $\begin{array}{l}2010- \\
2012\end{array}$ & $\begin{array}{l}2013- \\
2015\end{array}$ \\
\hline Allogeneic & Total, $n$ & & 1890 & 2221 & 2754 & 3115 & 3480 \\
\hline \multirow[t]{7}{*}{ Allogeneic } & \multirow[t]{4}{*}{$\mathrm{B}$ cell precursor } & Total & $1211(73)$ & $1535(73)$ & $1959(77)$ & $2166(75)$ & $2502(78)$ \\
\hline & & $\mathrm{Ph}$-negative & $327(27)$ & $343(22)$ & $342(17)$ & $380(17)$ & $452(18)$ \\
\hline & & $\mathrm{Ph}$-positive & $377(31)$ & 417 (27) & 729 (37) & $812(37)$ & $1003(40)$ \\
\hline & & Unknown, $n$ & 507 & 775 & 888 & 974 & 1047 \\
\hline & $\mathrm{T}$ cell precursor & & $403(24)$ & $539(26)$ & $591(23)$ & 704 (24) & $720(22)$ \\
\hline & Other & & $42(3)$ & $35(2)$ & $3(0)$ & $6(0)$ & $4(0)$ \\
\hline & Unknown, $n$ & & 234 & 112 & 201 & 239 & 254 \\
\hline \multirow[t]{8}{*}{ Autologous } & Total, $n$ & & 707 & 496 & 272 & 200 & 211 \\
\hline & \multirow[t]{4}{*}{ B cell precursor } & Total & 381 (59) & $259(55)$ & $165(64)$ & $110(60)$ & $127(65)$ \\
\hline & & $\mathrm{Ph}$-negative & $79(21)$ & $45(17)$ & $30(18)$ & $12(11)$ & $17(13)$ \\
\hline & & $\mathrm{Ph}$-positive & $63(17)$ & $37(14)$ & $50(30)$ & $44(40)$ & $60(47)$ \\
\hline & & Unknown, $n$ & 239 & 177 & 85 & 54 & 50 \\
\hline & $\mathrm{T}$ cell precursor & & $247(38)$ & $206(44)$ & $94(36)$ & $74(40)$ & $66(34)$ \\
\hline & Other & & $20(3)$ & $6(1)$ & $0(0)$ & $0(0)$ & $1(1)$ \\
\hline & Unknown, $n$ & & 59 & 25 & 13 & 16 & 17 \\
\hline
\end{tabular}

Data are $n(\%)$ using non-missing data unless specified otherwise. Only first allogeneic or autologous transplantations were included in the analysis $P h$ Philadelphia chromosome

Peripheral blood was the predominant source of stem cells, accounting for $61 \%$ of the allogeneic HSCT procedures in 2001-2003, with an increase up to $84 \%$ in $2013-$ 2015. In the most recent period, $16 \%$ of transplants were performed using bone marrow as a source of stem cells when compared to $38 \%$ in the period 2001-2003. Cord blood use was limited to less than $1 \%$ throughout the 15 year study period.

\section{HSCT rates per ALL incidence}

Age-standardized rates of first allogeneic HSCT performed in first CR, calculated per 100 diagnosed ALL incidence cases in patients aged 20 years and above, varied substantially among the analyzed countries (Fig. 2). The highest rates and most prominent increase in recent period were observed in Finland, followed by the
Table 3 Trends in the use of hematopoietic stem cell transplantation according to donor type and recipient age category

\begin{tabular}{lllllll}
\hline Donor type & Age (years) & Years & & & \\
\cline { 3 - 6 } & & $2001-2003$ & $2004-2006$ & $2007-2009$ & $2010-2012$ & $2013-2015$ \\
\hline Total allogeneic & $18-55$ & $1801(95)$ & $2069(93)$ & $2428(88)$ & $2679(86)$ & $2858(82)$ \\
& $>55$ & $89(5)$ & $152(7)$ & $326(12)$ & $436(14)$ & $622(18)$ \\
Matched sibling & $18-55$ & $958(94)$ & $1027(93)$ & $1054(88)$ & $1085(88)$ & $1009(85)$ \\
& $>55$ & $61(6)$ & $77(7)$ & $143(12)$ & $146(12)$ & $180(15)$ \\
Unrelated & $18-55$ & $756(97)$ & $961(93)$ & $1280(88)$ & $1452(84)$ & $1559(80)$ \\
& $>55$ & $26(3)$ & $75(7)$ & $176(12)$ & $274(16)$ & $394(20)$ \\
Mismatched related & $18-55$ & $87(98)$ & $81(100)$ & $94(93)$ & $142(90)$ & $290(86)$ \\
& $>55$ & $2(2)$ & $0(0)$ & $7(7)$ & $16(10)$ & $48(14)$ \\
Autologous & $18-55$ & $614(87)$ & $420(85)$ & $211(78)$ & $146(73)$ & $153(73)$ \\
& $>55$ & $93(13)$ & $76(15)$ & $61(22)$ & $54(27)$ & $58(27)$ \\
\hline
\end{tabular}

Data are $n(\%)$. Only first allogeneic or autologous transplantations were included in the analysis 
Table 4 Type of conditioning and stem cell sources for allogeneic hematopoietic stem cell transplantation in first complete remission

\begin{tabular}{|c|c|c|c|c|c|c|}
\hline & & \multicolumn{5}{|l|}{ Years } \\
\hline & & $2001-2003$ & 2004-2006 & 2007-2009 & 2010-2012 & 2013-2015 \\
\hline \multirow[t]{4}{*}{ Intensity of conditioning } & Total, $n$ & 1006 & 1347 & 1816 & 2108 & 2374 \\
\hline & Myeloablative & $901(94)$ & $1184(89)$ & $1537(86)$ & $1678(81)$ & $1689(73)$ \\
\hline & Reduced & $60(6)$ & $146(11)$ & $256(14)$ & 394 (19) & $625(27)$ \\
\hline & Unknown, $n$ & 45 & 17 & 23 & 36 & 60 \\
\hline \multirow[t]{4}{*}{ Myeloablative conditioning } & Total, $n$ & 901 & 1184 & 1537 & 1678 & 1689 \\
\hline & Chemotherapy based & $118(13)$ & $166(14)$ & $272(18)$ & $313(19)$ & $393(23)$ \\
\hline & TBI based & $783(87)$ & $1015(86)$ & $1263(82)$ & $1365(81)$ & $1294(77)$ \\
\hline & Unknown, $n$ & 0 & 3 & 2 & 0 & 2 \\
\hline \multirow[t]{4}{*}{ Reduced-intensity conditioning } & Total, $n$ & 60 & 146 & 256 & 394 & 625 \\
\hline & Chemotherapy based & $32(53)$ & $89(63)$ & $182(71)$ & $311(79)$ & $525(84)$ \\
\hline & TBI based & $28(47)$ & $53(37)$ & $74(29)$ & $83(21)$ & 99 (16) \\
\hline & Unknown, $n$ & 0 & 4 & 0 & 0 & 1 \\
\hline \multirow[t]{5}{*}{ Stem cell source } & Total, $n$ & 1006 & 1347 & 1816 & 2108 & 2374 \\
\hline & Bone marrow & $385(38)$ & $415(31)$ & $410(23)$ & $448(21)$ & $372(16)$ \\
\hline & Peripheral blood & $616(61)$ & $926(69)$ & $1401(77)$ & $1652(78)$ & $1994(84)$ \\
\hline & Cord blood & $3(0)$ & $6(0)$ & $4(0)$ & $4(0)$ & $4(0)$ \\
\hline & Unknown, $n$ & 2 & 0 & 1 & 4 & 5 \\
\hline
\end{tabular}

Data are $n(\%)$ using non-missing data unless specified otherwise

TBI total body irradiation

Netherlands and Sweden; the lowest rates were noted in Russia. In several countries, including Germany and Poland, a marked increase was observed between 2007 and 2009 compared with the preceding periods, followed by a plateau in 2010-2015.

No statistically significant associations could be demonstrated for HSCT rates with either HDI (Spearman correlation $=0.21 ; p=0.54$ ) or GDP per capita (Spearman correlation $=-0.08 ; p=0.81)$.

\section{Discussion}

This comprehensive analysis on the activity of transplantation for ALL showed a marked increase in the number of allogeneic HSCTs performed during a 15-year period (2001-2015), especially in first CR, as a consolidation strategy aimed to decrease relapse risk. This increased transplant activity was based on diverse reasons, such as (a) the use of highly effective TKIs in Ph-positive ALL, resulting in a significantly high
Fig. 2 Age-standardized rates of first allogeneic HSCT performed in first complete remission for ALL in selected European countries. $A L L$ acute lymphoblastic leukemia, HSCT hematopoietic stem cell transplantation

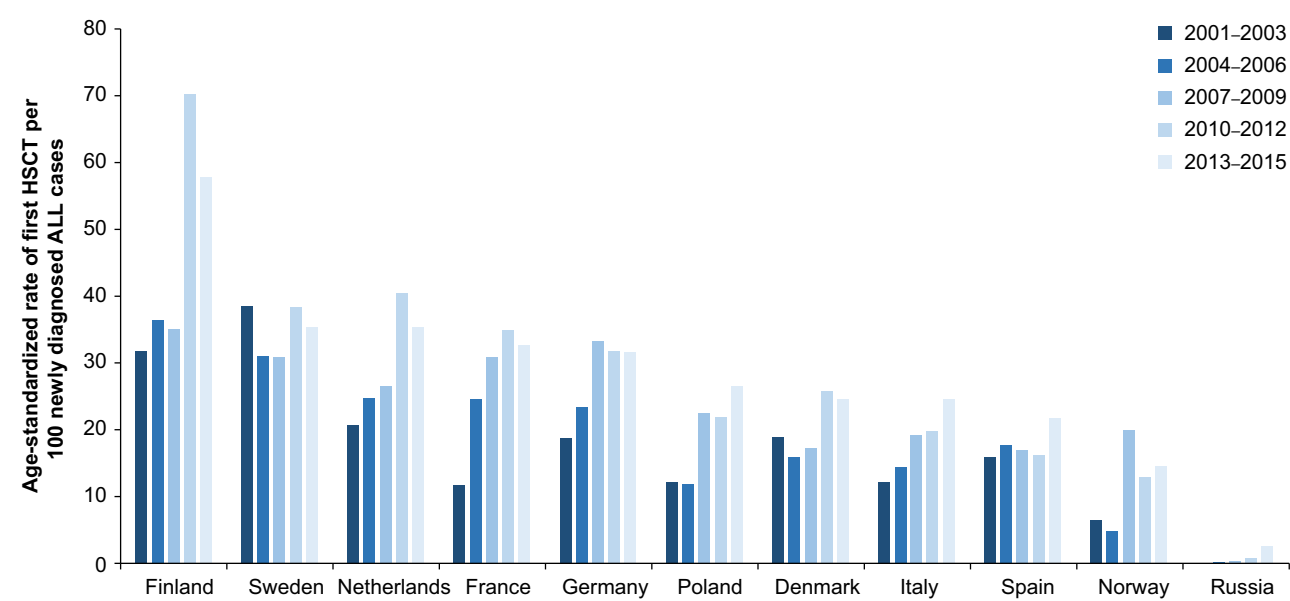


proportion of patients achieving a major response that allowed bridging to allogeneic HSCT; (b) the wider availability of unrelated donors that currently constitute the main donor source; and (c) the increased utility of RIC allogeneic HSCT, which expands the potential benefit of transplantation to the older ALL population.

Modern therapeutic protocols differ substantially for patients with $\mathrm{Ph}$-positive and $\mathrm{Ph}$-negative ALL. The presence of $t(9 ; 22)$ was traditionally considered a very-high-risk feature-associated with a lower chance of achieving CR and a very high probability of relapse [16]. Allogeneic HSCT provided the only reasonable chance of cure. The situation changed with the introduction of TKIs, which became widely available in the middle of the last decade. As demonstrated by studies comparing combined imatinib + chemotherapy with historical controls using chemotherapy alone, CR rates increased, followed by prolonged relapse-free survival [17]. However, without allogeneic HSCT, a majority of the patients ultimately relapse [18]. According to a study by Chalandon et al., allogeneic HSCT is still associated with significant benefit in terms of the overall survival in adults with Ph-positive ALL, treated initially with the combination of imatinib and reduced-dose chemotherapy [19]. The outcome may further be improved when TKIs are used as posttransplant maintenance [20]. Results of our retrospective database analysis indicate that the number of allogeneic HSCTs in first CR almost tripled for Ph-positive ALL within the 15 -year period. Clearly, the addition of imatinib to standard clinical practice improved the quality of response and reduced the risk of early relapse, therefore increasing the chance for patients to be treated with transplantation. In parallel, increasing availability of unrelated donors allowed for identification of HLA-compatible donors for the majority of patients in most European countries. More recently, the implementation of highly efficacious protocols of immunosuppression, such as the use of cyclophosphamide early after transplantation from haploidentical donors, offers the availability of a potential adequate donor to almost all patients in need of allogeneic HSCT. Hence, it may be anticipated that the number of transplants for adults with Ph-positive ALL will further increase. On the other hand, there are attempts to improve results of conventional-dose treatment regimens by adding second-generation (dasatinib, nilotinib) or third-generation (ponatinib) TKIs to first-line treatment. In a study by the European Working Group for Adult ALL, dasatinib in combination with chemotherapy was offered to patients older than 55 years, who are usually not candidates for myeloablative HSCT [21]. Despite a 65\% rate of major molecular responses, most patients relapsed within 5 years, leading to an overall survival probability of $35 \%$. Jabbour et al. reported the use of ponatinib in combination with intensive chemotherapy for younger adults with Ph-positive ALL [22]. The 2-year probability of event-free survival was $81 \%$, although allogeneic
HSCT was offered to only nine out of 37 patients. It must be stressed, however, that the follow-up of the study was relatively short, while long-term safety of ponatinib remains a matter of concern. Finally, with increasing efficacy of first-line treatment, it appeared that autologous HSCT followed by TKI maintenance may be a valuable alternative to allogeneic HSCT, especially for patients achieving molecular remission $[23,24]$. According to our current study, the use of autologous HSCT for patients with Ph-positive ALL was low and rather stable over time; however, we speculate that some increase may be anticipated in the future.

In contrast to Ph-positive ALL, treatment algorithms for adults with $\mathrm{Ph}$-negative disease are still based mainly on chemotherapy. In recent years, the chemotherapy protocols have been intensified following the pediatric experience in younger adults. The indications for allogeneic HSCT are usually based on risk stratification, with special attention put on the evaluation of response at the level of MRD. According to results of a study conducted by a French group using a pediatric-inspired protocol, patients who achieve an MRD level below $10^{-3}$ after induction chemotherapy do not necessarily benefit from allogeneic HSCT, regardless of the presence of conventional highrisk features [25]. Results of our study demonstrated a trend toward an increasing number of allogeneic HSCTs, although much less pronounced compared with Ph-positive ALL. Therefore, it may be speculated that the increasing availability of donors may be partially counterbalanced by restricted indications for HSCT in patients achieving MRD negativity. In the future, wide introduction of novel humoral and cellular immunotherapeutic approaches may change the landscape. The use of rituximab in first-line treatment has already been demonstrated to increase the probability of leukemia-free survival of patients with CD20-positive ALL [26]. Drugs like blinatumomab or inotuzumab ozogamicin are highly effective in the relapsed/refractory B cell precursor ALL setting and may serve as a bridge, enabling successful allogeneic HSCT $[8,9]$. On the other hand, when used frontline, they may increase the chance of MRD eradication, further limiting the role of transplant procedures.

ALL in elderly patients is associated with very poor prognosis due to the high risk of chemotherapy-related complications, hence the need for dose intensity reduction [27]. These patients are usually not candidates for transplantations with myeloablative preparative regimens. In late 1990s, RIC regimens were developed and introduced, allowing for wider application of allogeneic HSCT to older patients, including those with ALL [28]. This is reflected in the results of our study showing a seven-fold increase in the total number of allogeneic HSCT and 15-fold increase in the number of URD-HSCT for patients aged above 55 years. In similar proportions, the number of reported RIC procedures increased over time. Following general demographical trends toward increasing life expectancy, it may be anticipated that the number of older 
patients in need for allogeneic HSCT, and consequently, the number of procedures, will further grow in the future.

Numerous retrospective studies, including the recent analysis by our group [7], indicate that myeloablative TBI-based preparative regimens are more effective than chemotherapy-based conditioning, resulting in decreased risk of relapse and improved leukemia-free survival. Results of the current study confirm the predominant role of TBI in myeloablative setting, which was stable over time. It may be speculated, however, that with the development of new reduced-toxicity chemotherapy-based protocols, the landscape may change in the future. Encouraging results have already been reported for preparative regimens using thiotepa as a backbone [29]. Peripheral blood was the predominant source of stem cells over the entire study period showing a continuous increase over time. This phenomenon has been already reported for allogeneic HSCT in other indications [30].

Allogeneic HSCT is considered one of the most expensive medical procedures. The costs of URD-HSCT, most frequently used for patients with ALL, are particularly high and were calculated as US dollars (USD) 161,000 in Sweden and USD 152,000 in the Netherlands [31,32]. According to the analysis by Stranges et al., HSCTs were procedures with the most rapidly increasing costs of hospital stay in the USA between 2004 and 2007 [33]. The use of HSCT for adults with ALL varies greatly among countries, which may reflect that the availability of these procedures may be related to economic issues. However, results of our analysis do not show a clear correlation between HSCT rates and socioeconomic indices. Our findings suggest that the use of HSCT may be dependent on national guidelines, and the observed variation reflects heterogeneity of treatment approaches among countries. It should also be mentioned that the costs of novel drugs and cellular therapies may exceed the costs of HSCT.

Our study had some limitations, including any assumptions made regarding ALL incidence for the specified time period and possible variation in reporting to the EBMT registry from different countries over time. Despite that, we conclude that allogeneic HSCT remains a major tool in the fight against ALL in adults.

Funding The study was supported by a grant from Amgen Limited, London, UK. The authors would like to thank all EBMT centers reporting their data for the purpose of this analysis.

Data availability The datasets generated during and/or analyzed during the current study are available from the corresponding author on reasonable request.

\section{Compliance with ethical standards}

Conflict of interest SG has received honoraria for speaking at symposia and has participated in advisory boards for Amgen. AS and SW are employees of Amgen and own shares in Amgen. MM has received honoraria for speaking for Amgen and Pfizer. All other authors have no conflicts of interest.
Research involving human participants and/or animals All procedures performed in studies involving human participants were in accordance with the ethical standards of institutional and/or national research committees and with the 1964 Helsinki declaration and its later amendments or comparable ethical standards.

Informed consent Informed consent was obtained from all individual participants included in the study.

Open Access This article is distributed under the terms of the Creative Commons Attribution 4.0 International License (http:// creativecommons.org/licenses/by/4.0/), which permits unrestricted use, distribution, and reproduction in any medium, provided you give appropriate credit to the original author(s) and the source, provide a link to the Creative Commons license, and indicate if changes were made.

\section{References}

1. Inaba H, Greaves M, Mullighan CG (2013) Acute lymphoblastic leukaemia. Lancet 381:1943-1955

2. Gökbuget N, Dombret H, Ribera JM, Fielding AK, Advani A, Bassan R, Chia V, Doubek M, Giebel S, Hoelzer D, Ifrah N, Katz A, Kelsh M, Martinelli G, Morgades M, O'Brien S, Rowe JM, Stieglmaier J, Wadleigh M, Kantarjian H (2016) International reference analysis of outcomes in adults with $\mathrm{B}$-precursor $\mathrm{Ph}$-negative relapsed/refractory acute lymphoblastic leukemia. Haematologica 101:1524-1533

3. de Labarthe A, Rousselot P, Huguet-Rigal F, Delabesse E, Witz F, Maury S, Réa D, Cayuela JM, Vekemans MC, Reman O, Buzyn A, Pigneux A, Escoffre M, Chalandon Y, MacIntyre E, Lhéritier V, Vernant JP, Thomas X, Ifrah N, Dombret H, Group for Research on Adult Acute Lymphoblastic Leukemia (GRAALL) (2007) Imatinib combined with induction or consolidation chemotherapy in patients with de novo Philadelphia chromosome-positive acute lymphoblastic leukemia: results of the GRAAPH-2003 study. Blood 109:1408-1413

4. Goldstone AH, Richards SM, Lazarus HM, Tallman MS, Buck G, Fielding AK, Burnett AK, Chopra R, Wiernik PH, Foroni L, Paietta E, Litzow MR, Marks DI, Durrant J, McMillan A, Franklin IM, Luger S, Ciobanu N, Rowe JM (2008) In adults with standard-risk acute lymphoblastic leukemia, the greatest benefit is achieved from a matched sibling allogeneic transplantation in first complete remission, and an autologous transplantation is less effective than conventional consolidation/maintenance chemotherapy in all patients: final results of the International ALL Trial (MRC UKALL XII/ ECOG E2993). Blood 111:1827-1833

5. Gratwohl A, Pasquini MC, Aljurf M, Atsuta Y, Baldomero H, Foeken L, Gratwohl M, Bouzas LF, Confer D, Frauendorfer K, Gluckman E, Greinix H, Horowitz M, Iida M, Lipton J, Madrigal A, Mohty M, Noel L, Novitzky N, Nunez J, Oudshoorn M, Passweg J, van Rood J, Szer J, Blume K, Appelbaum FR, Kodera Y, Niederwieser D, Worldwide Network for Blood and Marrow Transplantation (WBMT) (2015) One million haemopoietic stemcell transplants: a retrospective observational study. Lancet Haematol 2:e91-e100

6. Luznik L, O'Donnell PV, Symons HJ, Chen AR, Leffell MS, Zahurak M, Gooley TA, Piantadosi S, Kaup M, Ambinder RF, Huff CA, Matsui W, Bolaños-Meade J, Borrello I, Powell JD, Harrington E, Warnock S, Flowers M, Brodsky RA, Sandmaier BM, Storb RF, Jones RJ, Fuchs EJ (2008) HLA-haploidentical bone marrow transplantation for hematologic malignancies using 
nonmyeloablative conditioning and high-dose, posttransplantation cyclophosphamide. Biol Blood Marrow Transplant 14:641-650

7. Giebel S, Labopin M, Socié G, Beelen D, Browne P, Volin L, Kyrcz-Krzemien S, Yakoub-Agha I, Aljurf M, Wu D, Michallet M, Arnold R, Mohty M, Nagler A (2017) Improving results of allogeneic hematopoietic cell transplantation for adults with acute lymphoblastic leukemia in first complete remission: an analysis from the Acute Leukemia Working Party of the European Society for Blood and Marrow Transplantation. Haematologica 102:139149

8. Kantarjian H, Thomas D, Jorgensen J, Jabbour E, Kebriaei P, Rytting M, York S, Ravandi F, Kwari M, Faderl S, Rios MB, Cortes J, Fayad L, Tarnai R, Wang SA, Champlin R, Advani A, O'Brien S (2012) Inotuzumab ozogamicin, an anti-CD22calecheamicin conjugate, for refractory and relapsed acute lymphocytic leukaemia: a phase 2 study. Lancet Oncol 13:403-411

9. Kantarjian HM, DeAngelo DJ, Stelljes M, Martinelli G, Liedtke M, Stock W, Gökbuget N, O'Brien S, Wang K, Wang T, Paccagnella ML, Sleight B, Vandendries E, Advani AS (2016) Inotuzumab ozogamicin versus standard therapy for acute lymphoblastic leukemia. N Engl J Med 375:740-753

10. Kantarjian H, Stein A, Gökbuget N, Fielding AK, Schuh AC, Ribera JM, Wei A, Dombret H, Foà R, Bassan R, Arslan Ö, Sanz MA, Bergeron J, Demirkan F, Lech-Maranda E, Rambaldi A, Thomas X, Horst HA, Brüggemann M, Klapper W, Wood BL, Fleishman A, Nagorsen D, Holland C, Zimmerman Z, Topp MS (2017) Blinatumomab versus chemotherapy for advanced acute lymphoblastic leukemia. N Engl J Med 376:836-847

11. Maude SL, Frey N, Shaw PA, Aplenc R, Barrett DM, Bunin NJ, Chew A, Gonzalez VE, Zheng Z, Lacey SF, Mahnke YD, Melenhorst JJ, Rheingold SR, Shen A, Teachey DT, Levine BL, June CH, Porter DL, Grupp SA (2014) Chimeric antigen receptor T cells for sustained remissions in leukemia. N Engl J Med 371:15071517

12. Cortes JE, Kim DW, Pinilla-Ibarz J, le Coutre P, Paquette R, Chuah C, Nicolini FE, Apperley JF, Khoury HJ, Talpaz M, DiPersio J, DeAngelo DJ, Abruzzese E, Rea D, Baccarani M, Müller MC, Gambacorti-Passerini C, Wong S, Lustgarten S, Rivera VM, Clackson T, Turner CD, Haluska FG, Guilhot F, Deininger MW, Hochhaus A, Hughes T, Goldman JM, Shah NP, Kantarjian H, Investigators PACE (2013) A phase 2 trial of ponatinib in Philadelphia chromosome-positive leukemias. N Engl J Med 369: 1783-1796

13. Human Development Report Team (2015) Human Development Report 2015: Work for Human Development. http://hdr.undp.org/ sites/default/files/2015_human_development_report.pdf. Accessed December 24, 2018

14. Bacigalupo A, Ballen K, Rizzo D, Giralt S, Lazarus H, Ho V, Apperley J, Slavin S, Pasquini M, Sandmaier BM, Barrett J, Blaise D, Lowski R, Horowitz M (2009) Defining the intensity of conditioning regimens: working definitions. Biol Blood Marrow Transplant 15:1628-1633

15. Giebel S, Marks DI, Boissel N, Baron F, Chiaretti S, Ciceri F, Cornelissen JJ, Doubek M, Esteve J, Fielding A, Foa R, Gorin NC, Gökbuget N, Hallböök H, Hoelzer D, Paravichnikova E, Ribera JM, Savani B, Rijneveld AW, Schmid C, WartiovaaraKautto U, Mohty M, Nagler A, Dombret H (2019) Hematopoietic stem cell transplantation for adults with Philadelphia chromosomenegative acute lymphoblastic leukemia in first remission: a position statement of the European Working Group for Adult Acute Lymphoblastic Leukemia (EWALL) and the Acute Leukemia Working Party of the European Society for Blood and Marrow Transplantation (EBMT). Bone Marrow Transplant 54:798-809

16. Wrzesień-Kuś A, Robak T, Pluta A, Zwolińska M, Wawrzyniak E, Wierzbowska A, Skotnicki A, Jakubas B, Hołowiecki J, Nowak K, Kuliczkowski K, Mazur G, Haus O, Dmoszyńska A, Adamczyk-
Cioch M, Jedrzejczak WW, Paluszewska M, Konopka L, Pałynyczko G (2006) Outcome of treatment in adults with Philadelphia chromosome-positive and/or BCR-ABL-positive acute lymphoblastic leukemia-retrospective analysis of Polish Adult Leukemia Group (PALG). Ann Hematol 85:366-373

17. Thomas DA, Faderl S, Cortes J, O'Brien S, Giles FJ, Kornblau SM, Garcia-Manero G, Keating MJ, Andreeff M, Jeha S, Beran M, Verstovsek S, Pierce S, Letvak L, Salvado A, Champlin R, Talpaz M, Kantarjian H (2004) Treatment of Philadelphia chromosomepositive acute lymphocytic leukemia with hyper-CVAD and imatinib mesylate. Blood 103:4396-4407

18. Vignetti M, Fazi P, Cimino G, Martinelli G, Di Raimondo F, Ferrara F, Meloni G, Ambrosetti A, Quarta G, Pagano L, Rege-Cambrin G, Elia L, Bertieri R, Annino L, Foà R, Baccarani M, Mandelli F (2007) Imatinib plus steroids induces complete remissions and prolonged survival in elderly Philadelphia chromosome-positive patients with acute lymphoblastic leukemia without additional chemotherapy: results of the Gruppo Italiano Malattie Ematologiche dell'Adulto (GIMEMA) LAL0201-B protocol. Blood 109:36763678

19. Chalandon Y, Thomas X, Hayette S, Cayuela JM, Abbal C, Huguet F, Raffoux E, Leguay T, Rousselot P, Lepretre S, Escoffre-Barbe M, Maury S, Berthon C, Tavernier E, Lambert JF, Lafage-Pochitaloff M, Lhéritier V, Chevret S, Ifrah N, Dombret H, Group for Research on Adult Acute Lymphoblastic Leukemia (GRAALL) (2015) Randomized study of reduced-intensity chemotherapy combined with imatinib in adults with $\mathrm{Ph}$-positive acute lymphoblastic leukemia. Blood 125:3711-3719

20. Pfeifer H, Wassmann B, Bethge W, Dengler J, Bornhäuser M, Stadler M, Beelen D, Vucinic V, Burmeister T, Stelljes M, Faul C, Dreger P, Kiani A, Schäfer-Eckart K, Schwerdtfeger R, Lange E, Kubuschok B, Horst HA, Gramatzki M, Brück P, Serve H, Hoelzer D, Gökbuget N, Ottmann OG, GMALL Study Group (2013) Randomized comparison of prophylactic and minimal residual disease-triggered imatinib after allogeneic stem cell transplantation for BCR-ABL1-positive acute lymphoblastic leukemia. Leukemia 27:1254-1262

21. Rousselot P, Coudé MM, Gokbuget N, Gambacorti Passerini C, Hayette S, Cayuela JM, Huguet F, Leguay T, Chevallier P, Salanoubat C, Bonmati C, Alexis M, Hunault M, Glaisner S, Agape P, Berthou C, Jourdan E, Fernandes J, Sutton L, Banos A, Reman O, Lioure B, Thomas X, Ifrah N, Lafage-Pochitaloff M, Bornand A, Morisset L, Robin V, Pfeifer H, Delannoy A, Ribera J, Bassan R, Delord M, Hoelzer D, Dombret H, Ottmann OG, European Working Group on Adult ALL (EWALL) group (2016) Dasatinib and low-intensity chemotherapy in elderly patients with Philadelphia chromosome-positive ALL. Blood 128:774-782

22. Jabbour E, Kantarjian H, Ravandi F, Thomas D, Huang X, Faderl S, Pemmaraju N, Daver N, Garcia-Manero G, Sasaki K, Cortes J, Garris R, Yin CC, Khoury JD, Jorgensen J, Estrov Z, Bohannan Z, Konopleva M, Kadia T, Jain N, DiNardo C, Wierda W, Jeanis V, O'Brien S (2015) Combination of hyper-CVAD with ponatinib as first-line therapy for patients with Philadelphia chromosomepositive acute lymphoblastic leukaemia: a single-centre, phase 2 study. Lancet Oncol 16:1547-1555

23. Gorin NC, Giebel S, Labopin M, Savani BN, Mohty M, Nagler A (2015) Autologous stem cell transplantation for adult acute leukemia in 2015: time to rethink? Present status and future prospects. Bone Marrow Transplant 50:1495-1502

24. Maury S, Chevret S, Thomas X, Heim D, Leguay T, Huguet F, Chevallier P, Hunault M, Boissel N, Escoffre-Barbe M, Hess U, Vey N, Pignon JM, Braun T, Marolleau JP, Cahn JY, Chalandon Y, Lhéritier V, Beldjord K, Béné MC, Ifrah N, Dombret $\mathrm{H}$, for GRAALL (2016) Rituximab in B-lineage adult acute lymphoblastic leukemia. N Engl J Med 375:1044-1053 
25. Giebel S, Labopin M, Gorin NC, Caillot D, Leguay T, Schaap N, Michallet M, Dombret H, Mohty M (2014) Improving results of autologous stem cell transplantation for Philadelphia-positive acute lymphoblastic leukaemia in the era of tyrosine kinase inhibitors: a report from the Acute Leukaemia Working Party of the European Group for Blood and Marrow Transplantation. Eur J Cancer 50: 411-417

26. Dhédin N, Huynh A, Maury S, Tabrizi R, Beldjord K, Asnafi V, Thomas X, Chevallier P, Nguyen S, Coiteux V, Bourhis JH, Hichri Y, Escoffre-Barbe M, Reman O, Graux C, Chalandon Y, Blaise D, Schanz U, Lhéritier V, Cahn JY, Dombret H, Ifrah N, GRAALL group (2015) Role of allogeneic stem cell transplantation in adult patients with Ph-negative acute lymphoblastic leukemia. Blood 125:2486-2496

27. Robak T, Szmigielska-Kapłon A, Wrzesień-Kuś A, Wierzbowska A, Skotnicki AB, Piatkowska-Jakubas B, Kuliczkowski K, Mazur G, Zduńczyk A, Stella-Hołowiecka B, Hołowiecki J, DwilewiczTrojaczek J, Madry K, Dmoszyńska A, Cioch M (2004) Acute lymphoblastic leukemia in elderly: the Polish Adult Leukemia Group (PALG) experience. Ann Hematol 83:225-231

28. Mohty M, Labopin M, Volin L, Gratwohl A, Socié G, Esteve J, Tabrizi R, Nagler A, Rocha V, Acute Leukemia Working Party of EBMT (2010) Reduced-intensity versus conventional myeloablative conditioning allogeneic stem cell transplantation for patients with acute lymphoblastic leukemia: a retrospective study from the European Group for Blood and Marrow Transplantation. Blood 116:4439-4443

29. Eder S, Beohou E, Labopin M, Sanz J, Finke J, Arcese W, Or R, Bonifazi F, Aljurf M, Socié G, Passweg J, Giebel S, Mohty M, Nagler A (2017) Thiotepa-based conditioning for allogeneic stem cell transplantation in acute lymphoblastic leukemia-a survey from the Acute Leukemia Working Party of the European Society for Blood and Marrow Transplantation. Am J Hematol 92:18-22

30. Passweg JR, Baldomero H, Bregni M, Cesaro S, Dreger P, Duarte RF, Falkenburg JH, Kröger N, Farge-Bancel D, Gaspar HB, Marsh J, Mohty M, Peters C, Sureda A, Velardi A, Ruiz de Elvira C, Madrigal A, European Group for Blood and Marrow Transplantation (2013) Hematopoietic SCT in Europe: data and trends in 2011. Bone Marrow Transplant 48:1161-1167

31. Svahn BM, Alvin O, Ringdén O, Gardulf A, Remberger M (2006) Costs of allogeneic hematopoietic stem cell transplantation. Transplantation 82:147-153

32. van Agthoven M, Groot MT, Verdonck LF, Löwenberg B, Schattenberg AV, Oudshoorn M, Hagenbeek A, Cornelissen JJ, Uyl-de Groot CA, Willemze R (2002) Cost analysis of HLAidentical sibling and voluntary unrelated allogeneic bone marrow and peripheral blood stem cell transplantation in adults with acute myelocytic leukaemia or acute lymphoblastic leukaemia. Bone Marrow Transplant 30:243-251

33. Stranges E, Russo CA, Friedman B (2006-2009) Procedures with the Most Rapidly Increasing Hospital Costs, 2004-2007: Statistical Brief \#82. Healthcare Cost and Utilization Project (HCUP) Statistical Briefs. Agency for Healthcare Research and Quality (US), Rockville https://www.ncbi.nlm.nih.gov/pubmed/21452489. Accessed November 30, 2018

Publisher's note Springer Nature remains neutral with regard to jurisdictional claims in published maps and institutional affiliations. 